\title{
Peningkatan Keaktifan Dan Prestasi Belajar Al-Qur'an Hadits Melalui Metode Diskusi Pada Siswa Kelas XI MAN 1 Kota Gorontalo Tahun pelajaran 2020/2021
}

\author{
Nurul Khoiriyah Hulawa \\ Guru MAN 1 Kota Gorontalo \\ nurul@gmail.com
}

\begin{abstract}
Received: 04 March 2021; Revised: 26 April 2021; Accepted: 28 August 2021
DOI: http://dx.doi.org/10.37905/aksara.7.3.1231-1236.2021
\end{abstract}

\begin{abstract}
Abstrak
Penelitian ini merupakan upaya untuk meningkatkan keaktifan dan prestasi belajar AlQuran Hadits melalui metode diskusi pada siswa kelas XI di MAN 1 Kota Gorontalo. Pertanyaan utama yang ingin dijawab melalui penelitian ini adalah (1) Apakah penerapan metode diskusi dapat meningkatkan keaktifan belajar Al-Al-Quran Hadits siswa Kelas XI Di MAN 1 Kota Gorontalo Tahun 2021?, dan (2) Apakah penerapan metode diskusi dapat meningkatkan prestasi belajar Al-Quran Hadits siswa Kelas XI Di MAN 1 Kota Gorontalo Tahun 2021? Untuk menjawab pertanyaan tersebut maka penelitian ini menggunakan penelitian tindakan kelas. Hasil belajar siswa pada mata pelajaran AlQur'an Hadits materi amar ma'ruf nahi mungkar yang pembelajarannya diterapkan metode pembelajaran diskusi adalah sedang dengan perincian dari 24 orang siswa terdapat 6 orang siswa atau 25\% memeperoleh nilai kategori tinggi, 17 orang atau 70,83\% memperoleh nilai sedang, dan 1 orang siswa atau 4,16\% memperoleh nilai kategori rendah dengan nilai rata-rata tes hasil belajar sebesar 78,33. Hasil belajar siswa pada mata pelajaran Al-Qur'an Hadits materi amar ma'ruf nahi mungkar yang pembelajarannya diterapkan metode ceramah adalah sedamg dengan perincian dari 22 orang siswa terdapat 2 orang siswa atau 9,09\% yang mendapat kategori nilai tinggi, 14 orang siswa atau 63,63\% memperoleh nilai kategori sedang dan 6 orang siswa atau 27,27\% memperoleh nilai kategori rendah dengan nilai rata-rata 68,68.3. Terdapat pengaruh yang signifikan metode pembelajaran diskusi terhadap hasil belajar Al-Qur'an Hadits siswa pada materi pembelajaran amar ma'ruf nahi mungkar di kelas XI MAN 1 Kota Gorontalo
\end{abstract}

Kata kunci: keaktifan siswa, prestasi belajar, metode diskusi

\section{PENDAHULUAN}

Pendidikan sangat penting untuk menghasilkan sumber daya manusia yang beriman dan bertakwa. Adanya kemajuan dalam pendidikan menimbulkan dorongan untuk melakukan inovasi pendidikan agar tercapai tujuan seperti yang diharapkan. Pendidikan adalah segala usaha orang dewasa dalam pergaulan dengan anak-anak untuk memimpin perkembangan jasmani dan rohaninya ke arah kedewasaan (Purwanto, 2007:11). 
Pendidikan dapat terwujud jika proses belajar mengajar diselenggarakan secara efektif, artinya dapat berlangsung secara lancar, terarah dan sesuai dengan tujuan pembelajaran.

Sekolah sebagai lembaga formal merupakan salah satu wadah untuk mewujudkan tujuan tersebut melalui kegiatan pembelajaran. Sekarang ini berbagai pendekatan maupun metode mengajar banyak digunakan agar tujuan dari proses pembelajaran dapat tercapai. Sampai saat ini pendidikan di indonesia masih didominasi oleh kelas yang berfokus pada guru sebagai pusat pengetahuan, sehingga ceramah akan menjadi pilihan utama dalam menentukan strategi belajar. Secara singkat belajar adalah suatu proses usaha yang dilakukan oleh individu untuk memperoleh suatu perubahan tingkah laku secara keseluruhan sebagi hasil pengalaman dalam interaksi dengan lingkungannya (Ahmadi, 2004:128).

Menurut pengamatan penulis selama ini pembelajaran Al-Quran Hadits MAN 1 Kota Gorontalo menjumpai adanya beberapa permasalahan, diantaranya adalah kurangnya guru menggunakan pendekatan dan metode yang tepat sehingga siswa kurang aktif dan bergairah dalam mengikuti pembelajaran di kelas sehingga prestasi belajar belum maksimal. Masih banyak siswa yang nilainya dibawah standar kriteria ketuntasan minimal (KKM) sehingga prestasi siswa menjadi rendah. Hal tersebut yang menjadikan alasan peneliti menggunakan metode diskusi dalam pembelajaran Al-Quran Hadits.

Untuk mengatasi masalah tersebut perlu digunakan suatu metode yang memberdayakan siswa salah satunya adalah melalui metode diskusi. Metode diskusi adalah suatu cara mempelajari materi pelajaran dengan memperdebatkan masalah yang timbul dan saling mengadu argumentasi secara rasional dan objektif (Anwar, 2001:85).

Dengan metode diskusi ini diharapkan proses belajar mengajar akan lebih menyenangkan dan lebih bermakna bagi siswa. Penerapan metode diskusi dapat memberikan pengalaman belajar kreatif yang bermakna pada siswa dalam mencapai ketuntasan belajar. Kemampuan siswa menjadi berkembang sehingga akan berpengaruh terhadap peningkatan prestasi belajar dalam bidang akademis dan spiritual siswa.

\section{METODE PENELITIAN}

Penelitian ini menggunakan penelitian tindakan kelas (PTK). Penelitian tindakan kelas adalah penelitian tindakan (Action Research) yang dilakukan untuk memperbaiki proses pembelajaran dengan harapan dapat meningkatkan mutu praktek pembelajaran di kelas (Syarifah,2007:2).

Subyek penelitian dalam penelitian ini adalah siswa-siswi kelas XI MAN 1 Kota Gorontalo pada Tahun 2021 pada mata pelajaran Al-Quran Hadits. Materi yang diajarkan adalah tata cara shalat wajib dan tata cara shalat jama'ah. Dalam penelitian ini subyek yang diteliti adalah siswa kelas XI yang berjumlah 24 siswa yang terdiri dari 11 siswa laki-laki dan 13 siswa perempuan.

Penelitian ini merupakan penelitian tindakan kelas (PTK), yaitu yang memfokuskan kelas sebagai bahan penelitian. Pada penelitian ini diupayakan tindakan praktis yang berupa penanggulangan masalah belajar siswa dan kesulitan mengajar guru. Proses tindakan ini dilaksanakan dalam bentuk pengkajian baru yang terdiri dari empat tahap yaitu perencanaan, pelaksanaan, observasi dan pengamatan. 
berikut :

Dalam penelitian ini, peneliti menggunakan metode pegumpulan data sebagai

a. Metode observasi

Metode observasi adalah suatu usaha sadar untuk mengumpulkan data yang dilakukan secara sistematis sesuai prosedur yang terstandar. Observasi ini dilakukan secara langsung dengan bantuan siswa untuk mengetahui keaktifan siswa di kelas. Dalam menggunakan metode observasi cara yang paling efektif adalah melengkapi format / blangko pengamatan sebagai instrument

b. Metode Dokumentasi

Metode dokumentasi ini penulis gunakan sebagai pelengkap dalam mengumpulkan data. Dalam menerapkan metode ini hanya digunakan untuk mengumpulkan data, yang berwujud surat - surat atau dokumentasi, jumlah siswa dan tenaga pengajar maupun sarana yang tersedia.

c. Tes

Tes yang sudah distandarisasi ialah tes yang telah mengalami proses validitas (ketepatan) dan reabilitas (ketetapan) untuk suatu tujuan tertentu dan untuk sekelompok siswa tertentu (Djamarah, 2000:218).

Untuk mengetahui keaktifan siswa dan keberhasilan dalam kegiatan pembelajaran perlu diadakan analisis data. Pada penelitian ini menggunakan tekhnik analisis deskriptif kualitatif yaitu metode penelitian yang bersifat menggambarkan kenyataan atau fakta sesuai dengan data yang diperoleh dengan tujuan mengetahui presentasi belajar yang dicapai siswa juga untuk memperoleh respon siswa terhadap kegiatan pembelajaran serta aktivitas selama proses pembelajaran. Untuk menganalisis tindakan keberhasilan atau prestasi keberhasilan siswa, maka dilakukan cara dengan memberikan evaluasi bersifat tertulis pada setiap akhir putaran.

\section{PEMBAHASAN}

Penelitian ini dilaksanakan di MAN 1 Kota Gorontalo di kelas XI. Penelitian dilaksanakan pada mata pelajaran Al-Qur'an Hadits materi amar makruf nahi mungkar. Penelitian dilaksanakan di dua kelas yaitu kelas eksperimen dan kontrol. Kegiatan penelitian dilakukan melelui pembelajaran di dua kelas yaitu kelas XI IPA dan kelas XI MAK. Pembelajaran di kelas XI IPA dilaksanakan menggunakan metode diskusi dan diikuti oleh 24 orang siswa. Pembelajaran di kelas XI MAK dilaksanakan menggunakan metode ceramah dan diikuti oleh 22 orang siswa. Pemebelajaran dilaksanakan oleh peneliti yang memiliki peran ganda yaitu sebagai peneliti sekaligus sebagai guru. Pada akhir pemebelajaran dilakukan tes untuk mengetahui hasil belajar siswa kedua kelas dan dianalisis dengan hasil sebagai berikut:

\section{Hasil Belajar Metode Diskusi}

Kelas eksperimen adalah kelas yang pembelajrannya menggunakan metode diskusi yaitu kelas XI IPA dengan jumlah siswa sebanyak 24 orang. Kegiatan pembelajaran dilaksanakan tiga kali pertemuan. Pada pertemuan pertama, kegiatan pembelajran kurang dapat berjalan maksimal karena siswa belum memahami langkah-langkah pembelajaran yang menggunakan metode diskusi. Oleh karena itu, pembelajaran pada pertemuan pertama masih bersifat pengenalan. Pada pertemuan kedua, siswa telah memahami langkah-langkah pembelajaran menggunakan metode 
diskusi sehingga pembelajaran dapat berjalan dengan maksimal. Pada pertemuan ketiga dilakukan evaluasi untuk mengetahui hasil belajar siswa setelah mengikuti pembelajaran menggunakan metode pembelajaran diskusi. Evaluasi dilaksanakan dengan memeberikan soal-soal berbentuk pilihan ganda sebanyak 20 nomor. Kegiatan evaluasi diikuti oleh seluruh siswa kelas XI IPA MAN 1 Kota Gorontalo berjumlah 24 orang siswa. Berdasarkan analisis hasil tes diketahui bahwa dari 24 orang siswa terdapat 6 orang siswa atau 25\% memeperoleh nilai kategori tinggi, 17 orang atau $70,83 \%$ memeperoleh nilai sedang, dan 1 orang siswa atau 4,16\% memeperoleh nilai kategori rendah dengan nilai rata-rata tes hasil belajar sebesar 78,33. Data tersebut menunjukkan bahwa hasil belajar siswa kelas eksperimen yaitu kelas XI MAN 1 Kota Gorontalo yang pembelajarannya menggunakan metode diskusi adalah sedang. Data hasil tes pada kelas eksperimen menunjukkan bahwa metode pembelajaran diskusi pada mata pelajara Al-Al-Quran Hadits. Melalui penerapan metode pembelajaran diskusi siswa berupaya aktif mengikuti seluruh kegiatan pembelajaran sehingga siswa lebih memahami materi pembelajaran.

2. Hasil Belajar Metode Ceramah

Kelas kontrol adalah kelas yang pembelajarannya menggunakan metode pembelajaran ceramah yaitu kelas XI MAK denagn jumlah siswa sebanyak 22 orang. Kegiatan pembelajaran dilaksanakan tiga kali pertemuan. Kegiatan pembelajara dilakukan sesuai dengan langkah-langkah kegiatan pembelajaran yaitu telah digunakan di kelas XI MAK yaitu menggunakan metode ceramah. Kegiatan pembelajaran dilakukan dengan memeberikan catatan kepada seluruh materi pembelajaran secara lisan. Setelah kegiatan pembelajaran berakhir, dilakukan tes untuk mengetahui hasil belajar siswa.

Berdasarkan analisis hasil tes diketahui bahwa dari 22 orang siswa terdapat 2 orang siswa atau $9,09 \%$ yang mendapat kategori nilai tinggi, 14 orang siswa atau $63,63 \%$ memperoleh nilai kategori sedang dan 6 orang siswa atau 27,27\% memperoleh nilai kategori rendah dengan nilai rata-rata 68,68. Data tersebut menunjukkan bahawa hasil belajar siswa kelas kontrol yang pembelajararannya menggunakan metode ceramah adalah sedang. Data hasil tes pada kelas kontrol menunjukkan bahwa metode pembelajaran ceramah kurang efektif diterapkan pada mata pelajaran Al-Qur'an Hadits. Pemnerapan metode pembelajaran ceramah memposisikan siswa sebagai objek belajar yang hanya mendengarkan penjelasan guru. Keadaan tersebut menjadikan aktivitas belajar siswa menjadi rendah. Bahkan, selama kegiatan pembelajaran siswa yang tidak mendengarkan penjelaskan guru, berbicara atau mengobrol dengan teman sebangku dan tidur.

3. Pengaruh Metode Diskusi Terhadap Hasil Belajar

Setelah masing-masing kelas diketahui dan dianalisis, langkah selanjutnya adalah melakukan analisis data untuk mengetahui ada tidaknya pengaruh metode pembelajaran diskusi terhadap hsil belajar Al-Qur'an Hadits.

Berdasarkan analisis hasil data tes bahwa terdapat pengaruh yang signifikan metode pembelajaran diskusi terhadap hasil belajar Al-Qur'an Hadits siswa pada materi pembelajaran amar ma'ruf nahi mungkar di kelas XI MAN 1 Kota Gorontalo. Analisis data hasil tes ke-2 menunjukkan hasil belajar Al-Qur'an Hadits pada materi amar makruf nahi mungkar siswa kelas XI IPA MAN 1 Kota Gorontalo yang pembelajarannya menggunakn metode diskusi lebih baik dari siswa yang 
menggunakan metode ceramah. Hal tersbut terbukti dalan tabel prosentase yang menunjukkan bahwa kelompok siswa yang yang pembelajarannya menggunakan metode pembelajaran diskusi terdapat 6 siswa (25\%) berada pada nilai kategori tinggi, sedangkan siswa yang menggunakan metode pembelajaran ceramah hanya 2 siswa $(9,09 \%)$ memperoleh nilai kategori nilai tinggi. Selain itu, pada kelas eksperimen 1 siswa $(4,16 \%)$ yang menperoleh kategori rendah, sedangkan pada kelas kontrol terdapat 6 siswa $(27,27 \%)$ memperoleh kategori rendah. Data hasil menunjukkan bahawa metode diskusi efektif digunakan atau diterapkan pada pembelajarn AlQur'qn Hadits. Metode pembelajar diskusi merupakan metode yang cara penyajian pelajaran dengan cara bersifat problematis untuk dibahas dan dikerjakan bersama. Melaui penerapan metode diskusi siswa dapat mengemukakan pendapat masingmasing dan mengembangkan ide pemikirannya secara bebas untuk memecahkaan masalah secara bersama-sama. Ketika dihadapkan dengan suatu permasalahan siswa dapat memecahkan masalah secara bersama-sama untuk mencari jawaban dan kebenaran atas suatu masalah. Penerapan metode pembelajaran diskusi menuntut untuk aktif mengikuti seluruh kegiatan pembelajaran dengan melakuakan berbgai kegiatan seperti mencari informasi maupun mengamati fenomena lingkungan sekitar untuk menyelesaiakan berbagai permasalahan sesuai materi pembelajaran. Pada kegiatan pembelajaran siswa lebih memahami materi pembelajaran Al-Qur'an Hadits melalui kegiatan mengumpulkan informasi dari lingkungan sekitar untuk menyelesaikan berbagai permasalahan dalam pembelajaran Al-Qur'an Hadits

\section{PENUTUP}

Hasil belajar siswa yang pembelajarannya dengan menggunakan metode pembelajaran diskusi terdapat 6 siswa yang terkualifikasi pada kategori tinggi, 17 siswa yang terkualifikasi dalam kategori sedang dan 1 siswa yang terkualifikasi dalam kategori rendah. Sedangkan nilai rata-rata kelas diperoleh 78,33. Hal ini berarti bahwa penerapan metode pembelajaran diskusi terhadap hasil belajar siswa pada materi pembelajaran Amar Makruf Nahi Mungkar dikelas XI MAN 1 Kota Gorontalo telah mencapai nilai KKM dengan baik karena nilai rata-rata kelas melebihi nilai KKM yang telah ditentukan. 2 . Hasil belajar siswa yang pembelajarannya dengan menggunakan metode pembelajaran ceramah terdapat 2 siswa yang terkualifikasi dalam kategori tinggi, 14 siswa yang terkualifikasi pada kategori sedang dan 6 siswa yang terkualifikasi pada kategori rendah. Sedangkan nilai rata-rata kelas diperoleh 68,86. Maka dapat dinyatakan bahwa penerapan metode pembelajaran ceramah terhadap hasil belajar siswa kelas XI MAN 1 Kota Gorontalo kurang tepat karenabelum bisa mencapai nilai KKM dengan baik. 3. Hasil pengujian hipotesis menunjukkan bahwa nilai haraga thitung lebih bersar dari tabel yaitu diperoleh harga thitung $=3,92$ dengan tabel $=2,024$. Hal ini berarti bahwa Ho ditolak dan Ha diterima. Maka dapat dinyatakan bahwa terdapat pengaruh yang signifikan penerapan metode pembelajaran diskusi terhadap hasil belajar siswa pada materi pembelajaran Amar Makruf Nahi Mungkar di kelas XI MAN 1 Kota Gorontalo. 


\section{DAFTAR PUSTAKA}

Djamaluddin.2009. Metode Pembelajaran. Jakarta. Bumi Aksara

Djamarah, Syaiful Bahri. 2010. Strategi belajar mengajar. Jakarta: Rineka Cipta. Jakarta: Raja Grafindo Persada.

Munijin Nasih.2009.Belajar dan Pembelajarn. Jakarta: Kharisma Putra Utama.

Purwanto, M. Ngalim. 2010. Psikologi Pendidikan. Bandung: Remaja Rosdakarya Sa'ud, Udin Syaefudin.2010. Inovasi Pendidikan . Bandung: Alfabeta

Sanjaya,Wina. 2012. Strategi Pembelajaran Berorientasi Standar Proses Pendidikan. Jakarta: Fajar Interpratama Offset.

Sudjana, Nana. 2005. Penelitian Pendidikan. Jakarta: Rineka Cipta. Sudjana. 2005. Metoda Statistika. Bandung: Tarsito.

Trianto, 2009. Mendesain Model Pembelajaran Inovatif - Progr esif. Jakarta: Kharisma Putra Utama 